BEATA SKRZYDLEWSKA* - LUBLIN

\title{
PROBLEMY I WYZWANIA MUZEALNICTWA KOŚCIELNEGO W POLSCE
}

Muzea religijne, czyli w sensie dosłownym muzea będące własnością różnych ugrupowań wyznaniowych, zaczęły powstawać w I poł. XIX w. Wśród nich najliczniejszą grupę stanowią muzea Kościołów chrześcijańskich, zwłaszcza Kościoła rzymskokatolickiego. Przeanalizowanie zagadnień ukazujących wyzwania i problemy muzealnictwa, pozwoli ukazać nie tylko pewien zakres przemian kulturowych i społecznych, jakie zachodziły na terenie Polski, ale także daje możliwość przedstawienia kondycji samego muzealnictwa kościelnego w Polsce oraz zadań, jakie ono realizuje.

U początków funkcjonowania muzeów kościelnych problemy, z którymi zmagali się ich twórcy były typowe dla instytucji, które dopiero się konstytuują. $\mathrm{Na}$ ziemiach polskich muzea Kościoła rzymskokatolickiego zaczęto organizować niewiele później niż na zachodzie Europy, bo w 2 poł. XIX wieku.

Badając dzieje tych instytucji zauważyć można, że wyraźnie zarysowują się cztery okresy ich rozwoju. Okres pierwszy rozpoczął się w $1870 \mathrm{r}$. w momencie otwarcia pierwszego muzeum diecezjalnego we Włocławku i trwał do czasu zakończenia I wojny światowej. Głównym problemem tamtego okresu wymagającym rozstrzygnięcia było sformułowanie koncepcji samego muzeum.

W czasie, kiedy konstytuowały się zbiory, prowadzone były dysputy nad ustalaniem modelu muzeum kościelnego. Zakładający muzea zadawali sobie pytanie, jaki powinny mieć charakter? Muzea tego typu zaczynały się dopiero organizować, dlatego brakowało wzorców, z których można było czerpać inspirację.

Prawdą jest, że powstające od poł. XIX w. muzea religijne miały swoje praźródło w skarbcach przykościelnych, jednak bliżej im do kolekcji z okresu potry-

* Beata Skrzydlewska - dr historii sztuki, e-mail: bskrzydlewska@o2.pl

${ }^{1}$ W. Szczebak, Muzeum Diecezjalne w Tarnowie, Tarnów 2003, s. 41-63; B. Skrzydlewska, Muzea Kościoła katolickiego w Polsce. Informator, Kielce 2004; taż, Muzeum Diecezjalne w Płocku na tle dziejów muzealnictwa kościelnego, „Muzealnictwo”, 49 (2008) s. 89-101; P. Mrozowski, Muzea Kościelne, w: Muzea polskie, red. D. Folga-Januszewska, Olszanica 2012, s. 56-75. 
denckiego. Może nie do tak bogatych kolekcji jak np. kardynała Fryderyka Boromeusza arcybiskupa Mediolanu, a do muzeów należących głównie do jezuitów, które powstawały przy seminariach duchownych czy ośrodkach formacyjnych głównie w celach edukacyjnych ${ }^{2}$.

Ale czy te wielkie zbiory mogły stanowić wzorzec dla muzeów diecezjalnych i parafialnych? Tylko częściowo, ponieważ organizujący je nie dysponowali takimi zasobami pieniężnymi, ani tak bogatymi zbiorami gromadzonymi w przemyślany sposób na przestrzeni wielu lat.

Innym problemem, przed którym stanęli wówczas organizatorzy muzeów był sposób pozyskiwania obiektów, a także znalezienie dla nich odpowiedniego miejsca przechowywania i ekspozycji. Ostatecznie, w muzeach tych chciano zgromadzić w jednym miejscu i zabezpieczyć przedmioty, które pozostały po kasacie klasztorów i obiekty wycofane z kultu. W Polsce będącej wówczas pod zaborami umieszczono w muzeach religijnych także pamiątki narodowe.

Kolejnym, bardzo istotnym problemem, był brak zapisów prawnych regulujących działalność tych placówek. Chociaż Kościół od czasów nowożytnych dbał o zabezpieczanie materialnych świadectw naszej kultury przed dewastacją, zabiegał o stworzenie im dobrych warunków m.in. wydając akta prawne dotyczące ochrony dóbr kultury, to dokument powołujący oficjalnie do życia muzea diecezjalne wydany został dopiero za pontyfikatu papieża Piusa X w $1907 \mathrm{r}^{3}$

W tym fundamentalnym dla muzealnictwa kościelnego czasie, powstało dziesięć muzeów diecezjalnych. Za pierwsze uważa się założone w 1870 r. Muzeum we Włocławku, powstałe staraniem związanych z diecezją dwóch kapłanów (braci) Stanisława i Zenona Chodyńskich ${ }^{4}$.

Drugi etap działalności muzeów Kościoła rzymskokatolickiego w Polsce trwał od 1918 r. do końca II wojny światowej. Jego początek zbiegł się z uzyskaniem przez Polskę niepodległości. W związku z tym nie kładziono już tak wielkiego nacisku na przechowywanie świeckich pamiątek narodowych, ponieważ znalazły one należyte schronienie w muzeach państwowych. W muzeach przykościelnych gromadzono głównie obiekty związane z dziedzictwem religijnym lub po prostu wycofane z kultu. Działające wówczas muzea były w większości instytucjami

2 M.C. Łubieński, Kardynal Fryderyk Boromeusz 1554-1631, twórca Ambrozjany, Kraków 1931; P. Krasny, Visibilia signa ad pietatem excitantes. Teoria sztuki sakralnej w pismach Roberta Bellarmina, Cezarego Baroniusza, Rudolfa Hospiniana, Fryderyka Boromeusza i innych pisarzy kościelnych epoki nowożytnej, Kraków 2010, s. 147-152.

${ }^{3}$ G. Mariani, La legislazione ecclesiastica In materia d'arte sacra, Roma 1952, s. 127.

${ }^{4}$ Drugą placówką, funkcjonującą nieprzerwanie do dnia dzisiejszego, było Muzeum Diecezjalne w Tarnowie. Rektor tamtejszego Seminarium Duchownego ks. infułat Józef Bąba w 1888 r. przekształcił w muzeum diecezjalne istniejący od 1882 r. przy seminarium gabinet sztuki. Inne powstałe na przestrzeni tych lat muzea diecezjalne to: muzeum w Poznaniu powołane przez abpa Floriana Stablewskiego (1893 r.), we Wrocławiu (1898 r.) założone przez kard. Jerzego Koppa, w Przemyślu (1902 r.), powstałe staraniem bpa Józefa Sebastiana Pelczara; w Płocku (1904 r.) utworzone za czasów bpa Jerzego Szembeka. Inne muzea to muzeum w Sandomierzu (1905 r.), Krakowie (1909 r.), Żytomierzu (1909) i w Warszawie (ok. 1910 r.); zob. W. Szczebak, Muzeum Diecezjalne w Tarnowie, Tarnów 2003; E. Różańska, Muzea diecezjalne w Polsce, Toruń 1976, mps KUL. 
bardzo dobrze zorganizowanymi. Oprócz powiększania zbiorów, zarządzający koncentrowali się na działalności znacznie szerzej zakrojonej: urządzano wystawy, wygłaszano prelekcje, prowadzono szkolenia dla księży w zakresie historii sztuki i ochrony zabytków, przeprowadzano inwentaryzację obiektów sztuki (nie tylko sakralnej) na terenie swoich diecezji.

$\mathrm{W}$ tym okresie, przynajmniej w początkowym jego etapie, problemem pozostawał nadal brak zapisów prawnych regulujących działalność muzeów. Częściowo tę kwestię rozwiązało wydanie Kodeksu Prawa Kanonicznego, któremu nadano moc obowiązującą dnia 19 maja 1918 rokus . Tak oczekiwany przez Kościół rzymskokatolicki dokument nie do końca jednak wyjaśniał kwestie odnoszące się do muzealnictwa. Rozwiązano je dopiero w roku 1924, kiedy Papieska Komisja Centralna Sztuki Kościelnej wydała szczegółowe Rozporzadzenia Papieskie w przedmiocie Sztuki Kościelnej ${ }^{6}$. Rozporządzenie było instrukcją pouczającą o opiece nad zbiorami archiwalnymi, bibliotecznymi i muzealnymi. Rozesłano je do wszystkich diecezji, m.in. do diecezji polskich. Preambułę rozporządzenia stanowiło Pismo Sekretariatu Stanu do Biskupów Włoskich, w którym uzasadniano okoliczności wydania aktu i powołania Komisji, podając jej ostateczny kształt i określając cele, jakim powinna służyć7

Zakres działalności Komisji był szeroki, a do jej obowiązków należało ułożenie inwentarza dzieł sztuki, zakładanie i urządzanie muzeów diecezjalnych, zatwierdzanie planów nowych budynków, a także restauracja starych, dbanie o podniesienie poziomu wiedzy o dobrach kultury poprzez wykłady, prelekcje i artykuły ${ }^{8}$. Rozporządzenie papieskie uznano za cenne źródło informacji w kwestii ochraniania mienia. Ustalono, że przy zawieraniu konkordatów ze Stolicą Apostolską rządy zainteresowanych państw będą musiały mieć je na względzie.

Aktualny pozostawał jednak problem pogodzenia prawa państwowego z prawem kościelnym. Uregulował to konkordat pomiędzy Rzeczpospolitą Polską a Stolicą Apostolską zawarty dnia 10 lutego 1925 r. Normalizował on stosunki między władzą kościelną i świecką, uwzględniając w nim także zagadnienia ochrony dóbr kultury9.

Po zawarciu konkordatu rozpoczęło się żywsze zainteresowanie sprawami dóbr kultury na synodach diecezjalnych. W okresie międzywojennym odbyto

\footnotetext{
${ }^{5}$ Codex iuris canonici Pii X Pontificis Maximi iussu digestus Benedicti Papae XV, Roma 1917. E. Przekop, Kościelna ochrona zabytków i dóbr kultury wedtug Kodeksu Prawa Kanonicznego papieża Jana Pawła II, „Archiwa Biblioteki i Muzea Kościelne” (dalej: ABMK), 54 (1987) s. 30-31.

${ }^{6}$ Rozporzadzenie Ojca Św. w sprawie sztuki Świętej, Watykan 1924; J. Pasierb, Ochrona zabytków sztuki kościelnej, Warszawa 1995, s. 22-23.

${ }^{7}$ Kardynał P. Gasparri, Pismo Sekretarjatu Stanu do Biskupów Włoskich, zawiadamiajace o założeniu w Rzymie Centralnej Komisji opieki nad zabytkami artystycznemi kościołów włoskich, Watykan 1.X.1924, w: Rozporządzenie Ojca Św. w sprawie Sztuki Świętej, Watykan 1924, s. 3-5.

${ }^{8}$ Tamże, s. 5.

${ }^{9}$ Konkordat zawarty pomiędzy Stolica Apostolska a Rzeczapospolita Polska, podpisany w Rzymie dnia 10 lutego 1925 r., Lwów 1925; S. Łukomski, Konkordat zawarty dnia 10 lutego 1925 roku pomiędzy Stolica Apostolska i Rzeczapospolita Polska, Łomża 1934, zob. J. Pasierb, Ochrona zabytków sztuki kościelnej, Warszawa 1995, s. 23.
} 
kilkanaście synodów i na wielu z nich podnoszono sprawę zachowania cennych pamiątek przeszłości. Między innymi w statutach synodu odbytego w Kielcach w 1927 roku kilka punktów poświęcono ochronie dóbr należących do Kościo$\mathfrak{1 a}^{10}$. Szczególne znaczenie dla ochrony dziedzictwa kulturowego mają uchwały synodu odbytego w Wilnie w 1931 roku. Synod wileński ustanowił Muzeum Diecezjalne i wydał Instrukcję o konserwacji zabytków sztuki, kultury i historii będacych w posiadaniu Kościoła na terenie Archidiecezji ${ }^{11}$.

$\mathrm{W}$ tym czasie do funkcjonujących już kościelnych placówek muzealnych w Polsce dołączyły nowe: we Lwowie (1916 r.), w Janowie (1920 r., w 1922 r. przeniesione do Siedlec), Kielcach (1922 r.), Lublinie (1926 r.), Pelplinie (1928 r.) i Łodzi (1937 r. $)^{12}$. Korzystny dla muzealnictwa okres przerwał wybuch II wojny światowej.

Okres trzeci trwał od momentu zakończenia II wojny światowej do 1989 roku. Wraz ze zmianą ustroju politycznego pojawiły się nowe problemy dotyczące ochrony dóbr kultury. Zadawano sobie pytanie, jak wobec wszechobecnej wówczas ideologii komunistycznej mającej charakter ateistyczny i niechętny w stosunku do Kościoła i jego instytucji, mają funkcjonować muzea kościelne. Niektóre muzea powstałe uprzednio zawiesiły swoją działalność, jednocześnie zbiory wielu z nich zaginęły bezpowrotnie podczas wojny albo zostały włączone do zbiorów muzeów państwowych. Ponadto w związku ze zmianą granic, miasta takie jak Lwów czy Wilno, w których funkcjonowały muzea religijne stały się częścią ZSRR, a muzea te zostały zlikwidowane.

$\mathrm{Z}$ czasem niektóre placówki zostały reaktywowane lub organizowano nowe muzea. Wśród nich wymienić należy muzea diecezjalne: w Lublinie (powołane na nowo w 1975 r.), w Łodzi (udostępnione zwiedzającym w 1970 r.), w Krakowie (1978 r.), w Warszawie (1980 r.), zaś dnia 21 listopada 1987 r. dzięki inicjatywie bpa Alfonsa Nossola otwarto, bardzo nowoczesne jak na tamte czasy, Muzeum Diecezjalne w Opolu ${ }^{13}$. W okresie tym powstaje wiele muzeów klasztornych, organizowane są także muzea parafialne, ale większość z nich to placówki filialne muzeów diecezjalnych, zwłaszcza Muzeum Diecezjalnego w Tarnowie ${ }^{14}$.

${ }^{10}$ Synodus Dioecesana Kielcensis 1927, Kielce 1927.

${ }^{11}$ Instrukcja o konserwacji zabytków sztuki, kultury i historii bęacych w posiadaniu Kościoła na terenie Archidiecezji, w: Synodus Archidiocesana Vilnensis ab Exellentissimo illusstrissimo ac reverendissimo Domino Domino Romualdo Jatbrzykowski S. Th. M. anno Domini MCMXXXI diebus 9, 10 et 11 mensis Iulii in Basilica Metropolitana Vilnensi S. S. Stanislai Em. et Vladislai RC. Celebrata, Vilno 1932, s. 381-392.

${ }^{12}$ Skrzydlewska, Muzea Kościoła katolickiego w Polsce, s. 14, przypis 7.

${ }^{13}$ K. Burek, Muzeum Archidiecezji Warszawskiej, ABMK, 54 (1987) s. 140-145; J. Spychała, Muzeum Archidiecezji Łódzkiej od utworzenia po dziś, „Wędrownik-Biuletyn krajoznawczy. RPK, PTTK w Łodzi”, 3-4 (1994) s. 341; P. Maniurka, Muzeum diecezjalne. Założenia, realizacja i funkcjonowanie na przykładzie Muzeum Diecezjalnego w Opolu, ABMK, 63 (1994) s.61-64; M. Sawicki, Muzeum Archidiecezjalne w Lublinie, „Muzealnictwo”, 49 (2008) s. 139-147.

${ }^{14}$ Wśród muzeów klasztornych np. Muzeum Karmelitów Bosych w Czernej k. Krzeszowic (1971), Muzeum Misyjne Towarzystwa Salezjańskiego w Czerwińsku nad Wisłą, Muzeum Prowincji Ojców Bernardynów w Leżajsku. Muzea parafialne to m.in. Muzeum w Iwkowej (założone przez ks. Jana Piechotę w 1966 r.), w Bobowej (założone przez ks. Stanisława Chrzana w 1986) i w Paszynie (złożone przez ks. Edwarda Nitkę w 1972 r); zob.B.J. Wanat, Maryjne Sanktuarium Kar- 
Kwestią sporną pozostaje pogodzenie prawa kościelnego z prawem państwowym. Prawo kościelne dotyczące ochrony dóbr kultury było respektowane jedynie w obrębie Kościoła, zaś dokumenty państwowe, które przez Kościół musiały być respektowane jak Ustawa z dnia 15 lutego 1962 r. o ochronie dóbr kultury i muzeach, nie zawsze były dla Kościoła interpretowane korzystnie.

Wśród ważnych zagadnień, wymagających rozwiązania były te związane z organizacją muzeów i ich uposażeniem. Koniecznością było wyznaczenie ram organizacji wewnętrznej muzeów poprzez sporządzenie statutów, a tych większość muzeów nie posiadała. Dużą rolę w rozwiązywaniu ważnych kwestii muzealnych odegrał Ośrodek Archiwów, Bibliotek i Muzeów Kościelnych powołany w 1956 roku przy Katolickim Uniwersytecie Lubelskim. Ośrodek pełnił rolę koordynatora działalności muzeów. Jednym z głównym jego zadań było szerzenie wśród opiekunów zbiorów kościelnych wiedzy muzealnej (praktycznej i teoretycznej) poprzez wymianę doświadczeń, a także publikacje w wydawanym przez Ośrodek ABMK od 1959 r. czasopiśmie „Archiwa, Biblioteki i Muzea Kościelne”15.

Zmiany, które nastąpiły w naszym kraju po 1989 r. otworzyły nową kartę w dziejach kościelnego muzealnictwa - IV etap ich działalności. Od tego momentu, początkowo krok po kroku, z czasem coraz bardziej dynamicznie zaczęły rozwijać się muzea Kościoła rzymskokatolickiego.

W tym okresie zaczęto baczniej przyglądać się muzeom już istniejącym. Rozważano sposoby polepszania warunków koniecznych do ich prawidłowego działania i prężnego rozwoju. Możliwe stało się - niepodszyte obawami - współdziałanie z instytucjami państwowymi związanymi z kulturą. Dyrektorzy muzeów zaczęli podejmować próby gruntownego inwentaryzowania zbiorów na nośnikach multimedialnych, niejednokrotnie zlecano to zadanie studentom historii sztuki. Tym sposobem sporządzono na nowo inwentarze m.in. dla muzeów diecezjalnych w Przemyślu, Sandomierzu, Kielcach, Pelplinie, Łowiczu oraz muzeum misjonarzy w Krakowie ${ }^{16}$.

Zaczęto podejmować próby polepszania warunków lokalowych - powiększano zaplecza dla uzyskania miejsca na magazyny, pracownie konserwacji, a także reorganizowano wystawy. Mając zaś możliwość pozyskania zewnętrznych środków finansowych, tworzono ekspozycje według nowoczesnych trendów, np. w Płocku czy Sandomierzu.

W pierwszych latach XXI wieku wznowiły działalność muzea, które prze-

melitów w Czernej. Przewodnik, Kraków 1992; T. Bukowski, Urządzenie i funkcjonowanie muzeum parafialnego, ABMK , 79 (2003) s. 155.

${ }^{15}$ M. Dębowska, Ośrodek Archiwów, Bibliotek i Muzeów Kościelnych Katolickiego Uniwersytetu Jana Pawła II 1956-2006, Lublin 2006, s. 177-190; A. Hamryszczak, Bibliografia zawartości pótrocznika „Archiwa Biblioteki i Muzea Kościelne”. Tomy 1-100, ABMK, 101 (2014) s. 5-91; B. Skrzydlewska, Badania nad muzealnictwem kościelnym w Ośrodku Archiwów Bibliotek i Muzeów Kościelnych w latach 1956-2013. Bibliografia zawartości czasopisma „Archiwa Biblioteki i Muea Kościelne" w zakresie sztuki i muzealnictwa, w: Czasopisma archiwów, bibliotek i muzeów Kościoła katolickiego, red. W. Żurek, Lublin 2014, s. 159-181.

${ }^{16}$ Studenci historii sztuki Katolickiego Uniwersytetu Lubelskiego Jana Pawła II w ramach praktyk kończących IV i obecnie II rok studiów zinwentaryzowali zbiory wymienionych muzeów. 
stały funkcjonować po II wojnie światowej. Wprawdzie trudno mówić tutaj o reaktywacji starych muzeów, bowiem zbiory czy ich lokalizacja były częstokroć inne niż uprzednio, to jednak powołując placówkę w miejscu dawnego muzeum, chciano kontynuować rozpoczętą przed stu laty tradycję. W ten sposób powstały muzea: w Siedlcach (2000 r.), Włocławku (2005 r.) i Kielcach (2005 r.) ${ }^{17}$.

Duży wpływ na rozwój muzeów kościelnych powoływanych do życia przez przedstawicieli Kościoła rzymskokatolickiego miały przeobrażenia polityczne, które przyczyniły się pośrednio do zmian w strukturach kościelnych. W $1992 \mathrm{r}$. na mocy bulli papieskiej Totus Tuus Poloniae Populus dokonano reorganizacji w strukturach Kościoła w Polsce. Powstało wówczas 12 nowych diecezji oraz 5 nowych metropolii. Wiele $\mathrm{z}$ tych diecezji utworzyło własne muzea: Muzeum Diecezjalne w Zamościu (założone przez bpa Mariusza Leszczyńskiego, erygowane w 1995 r.), Muzeum Diecezjalne w Szczecinie (otwarte podczas inauguracji roku akademickiego 1990/1991 r.), Muzeum Diecezjalne w Siedlcach (2000 r.), Muzeum Diecezjalne w Rzeszowie (1998 r. $)^{18}$.

Wejście w 2004 r. Polski w struktury Unii Europejskiej dało szansę korzystania z tzw. programów unijnych - dzięki uzyskanemu tą drogą dofinansowaniu zarządzający budowlami sakralnym starają się o pozyskiwanie funduszy na ich remonty, a także na zakładanie placówek muzealnych.

Właśnie dzięki pozyskanym środkom unijnym powstały liczne muzea kościelne, m.in.: wspomniane już tutaj diecezjalne we Włocławku, a także Muzeum 200-lecia Diecezji w Lublinie, Muzeum Diecezjalne w Łowiczu, Muzeum przy kościele pobrygidkowskim w Lublinie, Muzeum przy Wyższym Seminarium Duchownym w Lublinie, czy Muzeum przy Sanktuarium Matki Bożej Kębelskiej w Wąwolnicy ${ }^{19}$.

Niebagatelny wpływ na obecny kształt muzeów religijnych miały zmiany wprowadzone w ustawodawstwie państwowym, ponieważ uchwalono nową Ustawe o ochronie zabytków i opiece nad zabytkami oraz nową Ustawę o mu$z e a h^{20}$. Po podpisaniu konkordatu między Stolicą Apostolską a Rzeczpospolitą Polską dnia 28 lipca 1993 r., ustawy te uwzględniać powinni organizujący muzea przykościelne ${ }^{21}$.

Szczególnie ważne dokumenty regulujące przepisy odnoszące się do ochrony dóbr kultury opracowała Papieska Komisja ds. Kościelnych Dóbr Kultury. Pierwszym z nich był wydany w 1999 r. list okólny Konieczność i pilna potrzeba inwentaryzacji oraz katalogowania dóbr kulturowych Kościoła. Omówione są tam m.in. sposoby katalogowania dóbr kultury a także wymienione są odpowiedzialne za to organa ${ }^{22}$.

${ }^{17}$ T. Kulik, Muzeum Diecezjalne w Siedlcach, ABMK, 54 (1987) s. 128.

${ }^{18}$ Skrzydlewska, Muzea Kościoła katolickiego w Polsce, s. 119, 124-126, 159.

${ }^{19}$ B. Skrzydlewska, Współczesne muzea religijne archidiecezji lubelskiej. Realizacje i projekty, ABMK, 100 (2013) s. 315-324.

${ }^{20}$ Ustawa z dnia 23 lipca 2003 r.o ochronie zabytków i opiece nad zabytkami, Dz.U. 2003, nr 162, poz. 1568; Ustawa z dnia 21 listopada 1996 r. o muzeach, Dz.U. 1997, nr 5, poz. 24.

${ }^{21}$ Konkordat między Stolicą Apostolską a Rzecząpospolitą Polską, podpisany w Warszawie dnia 28 lipca 1993 r., Dz.U. 1993, nr 51, poz. 318.

${ }^{22}$ Papieska Komisja ds. Kościelnych Dóbr Kultury, List okólny Konieczność inwentaryzacji i katalogowania dóbr kultury, 8 XII 1999 r.; M. Leszczyński, Ochrona zabytków sztuki sakralnej w 
Nowy kierunek działania muzeów religijnych sformułowano w kolejnym liście okólnym z dnia 15 sierpnia 2001 r. o Funkcji pastoralnej muzeów kościel$n y c h^{23}$. Dążeniem komisji formułującej dokument było skierowanie uwagi nie tylko osób duchownych, ale i świeckich na dziedzictwo historyczno-artystyczne Kościoła $\mathrm{w}$ wymiarze duszpasterskim. Zaznaczono wyraźnie, że muzeum kościelne dokumentując poprzez gromadzenie dzieł sztuki drogę Kościoła na przestrzeni wieków, nie powinno być oderwane od działalności duszpasterskiej ${ }^{24}$.

Dokument podzielony został na pięć zasadniczych części: Zachowanie dziedzictwa historyczno-artystycznego Kościoła, Natura, cele i typologia muzeum kościelnego, Organizacja muzeum kościelnego, Użyteczność muzeum kościelnego i Formacja pracowników muzeów kościelnych ${ }^{25}$. W liście zwrócono uwagę, że w okresie posoborowym wzrosła znacząco liczba muzeów kościelnych. Obok istniejących od kilkuset lat skarbców i nieco późniejszych muzeów katedralnych, powstają współcześnie muzea diecezjalne, muzea parafialne, zakonne, muzea instytutów religijnych, a także wspólnot i różnych instytucji Kościoła ${ }^{26}$.

Z przedstawionych powyżej kwestii dotyczących muzealnictwa kościelnego wyłania się korzystny obraz. Rzeczywistość okazuje się jednak bardziej skomplikowana. Wraz z niezaprzeczalnymi zmianami na lepsze, pojawiło się też szereg problemów, wynikających między innymi z interpretacji państwowych przepisów prawnych, zarówno kościelnych jak i państwowych.

Na podstawie prawa kościelnego powołanie muzeum kościelnego leży w gestii biskupa ordynariusza. W przypadku zakładania muzeum zakonnego decyzję taką wydają przełożeni zakonni. Według przytoczonego powyżej listu okólnego $\mathrm{z}$ dnia 15 sierpnia $2001 \mathrm{r}$. muzeum posiadać powinno statut i regulamin - jednak wiele z muzeów nie posiada statutów.

Obecnie przy okazji renowacji wielu świątyń, sytuowane są w budynkach przykościelnych, a nawet w kościołach, ekspozycje wystawiennicze noszące nazwy: skarbiec, najczęściej jednak muzeum.

Przyglądając się im od strony organizacyjno-prawnej niejednokrotnie rodzi się pytanie, czy placówka nazywana muzeum ma faktycznie status muzeum, czy jest muzeum tylko z nazwy? Faktem jest, że instytucje kościelne muszą mieć na względzie przepisy Kodeksu Prawa Kanonicznego, normy i zalecenia Konferencji Episkopatu Polski i biskupa ordynariusza, ale także muszą zastosować się do zaleceń państwowych.

Jeżeli mamy do czynienia $z$ instytucją muzealną to, dlaczego muzealia pozostają nadal wpisane do rejestru zabytków, skoro powinny być z rejestru wykreślone. Czyją więc są własnością obiekty znajdujące się w muzeach? Kolejną kwe-

świetle aktualnego prawa Kościoła katolickiego, „Muzealnictwo”, 49 (2008) s. 79-88.

${ }^{23}$ Papieska Komisja ds. Kościelnych Dóbr Kultury, List okólny Funkcja pastoralna muzeów kościelnych, 15 VIII 1999 r., thum. ks. F. Nieckarz, „Biuletyn Muzeum Diecezjalnego”, 4 (2000-2001) s.5-76; M. Leszczyński, Ochrona zabytków sztuki sakralnej w świetle aktualnego prawa Kościoła katolickiego, s. 79-88.

${ }^{24}$ List okólny Funkcja pastoralna muzeów, s. 6.

${ }^{25}$ Tamże, s. 32-72.

${ }^{26}$ Tamże, s. 14, 26-27. 
stią wymagającą rozstrzygnięcia jest ta, czy obiekty będące własnością muzeów, chociaż są wyłączone z kultu religijnego, powinny być zabierane z ekspozycji i włączane do kultu?

Pytaniem narzucającym się coraz częściej jest też to, czy organizowanie muzeów religijnych wynika głównie $z$ autentycznej chęci przechowywania i prezentowania dziedzictwa kulturowego w sposób właściwy muzeom, czy jest tylko ostatnim punktem w procesie realizacji odnowy budynku kościelnego.

Liczba tych placówek jest obecnie bardzo duża, w samym tylko Lublinie jest obecnie pięć muzeów religijnych. Może lepszym rozwiązaniem byłoby włączenie zbiorów do muzeów diecezjalnych, lub gdyby stanowily jednostki filialne tychże.

Trudnym zagadnieniem są stale kwestie finansowe. Mimo sporych obecnie możliwości pozyskiwania środków finansowych na zorganizowanie muzeum, niemałym problemem jest zdobycie funduszy na długoterminową działalność muzeów.

Ważną kwestią pozostaje kwestia związana z procesem kształcenia przyszłych kapłanów w dziedzinie historii sztuki, czy dokształcania zarządców kościołów w zakresie ochrony dóbr kultury. Zajęcia w seminariach duchownych w zakresie dóbr kultury mają bardzo często charakter fakultatywny, zaś liczba godzin jest niewystarczająca do zdobycia wiedzy, która dawałaby podstawy opiekowania się dziełami sztuki nie mówiąc już o zarządzaniu dobrami kultury.

Zarysowana tutaj w skrócie na tle historycznym problematyka dotycząca muzealnictwa kościelnego, pozwala zauważyć, że w dziedzinie tej realizowane są różne zadania - na każdym etapie inne - które wypływają ze stawianych przez organizatorów i zarządców dobrami kultury celów. W pierwszym etapie działalności muzeów religijnych, głównym zadaniem było zgromadzenie w jednym miejscu i zabezpieczenie przed zniszczeniem obiektów pozostałych po kasatach klasztorów i wycofanych z kultu. Dużym wyzwaniem było wówczas wypracowanie modelu muzeum.

W drugim etapie aktywności najważniejszym zadaniem było skodyfikowanie prawa dotyczącego ochrony zabytków i muzealnictwa.

Dużym wyzwaniem był okres trzeci, kiedy należało wyznaczyć ramy organizacji wewnętrznej muzeów poprzez sporządzenie statutów, zaś kwestią sporną było pogodzenie prawa kościelnego z prawem państwowym.

Współcześnie głównym zadaniem jest ukierunkowanie działalności muzeów kościelnych przede wszystkim na działalność duszpasterską Kościoła.

słowa kluczowe: muzealnictwo, muzea kościelne, dokumenty prawne, Kodeks Prawa Kanonicznego, konkordat, zabytki 


\section{BIBLIOGRAFIA}

\section{Źródla}

Codex iuris canonici Pii X Pontificis Maximi iussu digestus Benedicti Papae XV, Roma 1917.

Instrukcja o konserwacji zabytków sztuki, kultury i historii będących w posiadaniu Kościoła na terenie Archidiecezji, w: Synodus Archidiocesana Vilnensis ab Exellentissimo illusstrissimo ac reverendissimo Domino Domino Romualdo Jałbrzykowski S. Th. M. anno Domini MCMXXXI diebus 9, 10 et 11 mensis Iulii in Basilica Metropolitana Vilnensi S. S. Stanislai Em. et Vladislai RC. Celebrata,Vilno 1932.

Konkordat między Stolicą Apostolską a Rzecząpospolitą Polską, podpisany w Warszawie dnia 28 lipca 1993 r., Dz.U. 1993, nr 51.

Konkordat zawarty pomiędzy Stolicą Apostolską a Rzecząpospolitą Polską, podpisany w Rzymie dnia 10 lutego 1925 r., Lwów 1925.

Necessità e urgenza dell inentarazione e della catalogazione dei beni culturali della Chiesa. Città del Vaticano, 8 dicembre 1999.

Papieska Komisja ds. Kościelnych Dóbr Kultury, List okólny Funkcja pastoralna muzeów kościelnych, 15 VIII 1999 r., thum. Ks. F. Nieckarz, Biuletyn Muzeum Diecezjalnego 4 (2000-2001), s. 5-76.

Rozporządzenie Ojca Św. w sprawie sztuki Świętej, Watykan 1924.

Synodus Dioecesana Kielcensis 1927, Kielce 1927.

Ustawa z dnia 21 listopada 1996 r. o muzeach, Dz.U. 1997, nr 5.

Ustawa z dnia 23 lipca 2003 r.o ochronie zabytków i opiece nad zabytkami, Dz.U. 2003, nr 162, poz. 1568

\section{Opracowania}

Bukowski T., Urządzenie i funkcjonowanie muzeum parafialnego, „Archiwa Biblioteki i Muzea Kościelne", 79 (2003) s. 151-159.

Burek K., Muzeum Archidiecezji Warszawskiej, „Archiwa Biblioteki i Muzea Kościelne”, 54 (1987) s. 140-145.

Dębowska M., Ośrodek Archiwów, Bibliotek i Muzeów Kościelnych Katolickiego Uniwersytetu Jana Pawła II 1956-2006, Lublin 2006.

Hamryszczak A., Bibliografia zawartości półrocznika „Archiwa, Biblioteki i Muzea Kościelne”, Tomy 1-100, „Archiwa Biblioteki i Muzea Kościelne”, 101 (2014) s. 5-91.

Krasny P., Visibilia signa ad pietatem excitantes. Teoria sztuki sakralnej w pismach Roberta Bellarmina, Cezarego Baroniusza, Rudolfa Hospiniana, Fryderyka Boromeusza i innych pisarzy kościelnych epoki nowożytnej, Kraków 2010.

Leszczyński M., Ochrona zabytków sztuki sakralnej w świetle aktualnego prawa Kościoła katolickiego, „Muzealnictwo”, 49 (2008) s. 79-88.

Łubieński M.C., Kardynał Fryderyk Boromeusz 1554-1631, twórca Ambrozjany, Kraków 1931.

Łukomski S., Konkordat zawarty dnia10 lutego 1925 roku pomiędzy Stolicą Apostolską i Rzecząpospolitą Polską, Łomża 1934.

Maniurka P., Muzeum diecezjalne. Założenia, realizacja i funkcjonowanie na przykładzie Muzeum Diecezjalnego w Opolu, „Archiwa Biblioteki i Muzea Kościelne”, 63 (1994) s. 61-64.

Mariani G., La legislazione ecclesiastica In materia d'arte sacra, Roma 1952.

Mrozowski P., Muzea Kościelne, w: Muzea polskie, red. D. Folga-Januszewska, Olszanica, 2012, s. 56-75.

Pasierb J., Ochrona zabytków sztuki kościelnej, Warszawa 1995. 
Przekop E., Kościelna ochrona zabytków i dóbr kultury według Kodeksu Prawa Kanonicznego papieża Jana Pawła II, „Archiwa Biblioteki i Muzea Kościelne”, 54 (1987) s. $30-40$.

Sawicki M., Muzeum Archidiecezjalne w Lublinie, „Muzealnictwo”, 49 (2008) s. 139147.

Skrzydlewska B., Badania nad muzealnictwem kościelnym w Ośrodku Archiwów Bibliotek i Muzeów Kościelnych w latach 1956-2013. Bibliografia zawartości czasopisma „Archiwa Biblioteki i Muzea Kościelne” w zakresie sztuki i muzealnictwa, w: Czasopisma archiwów, bibliotek i muzeów Kościoła katolickiego, red. W. Żurek, Lublin 2014, s. 159-181.

Skrzydlewska B., Muzeum Diecezjalne w Płocku na tle dziejów muzealnictwa kościelnego, „Muzealnictwo”, 49 (2008) s. 89-101.

Skrzydlewska B., Muzea Kościoła katolickiego w Polsce. Informator, Kielce 2004.

Skrzydlewska B., Współczesne muzea religijne archidiecezji lubelskiej. Realizacje i projekty, „Archiwa Biblioteki i Muzea Kościelne”, 100 (2013), s. 315-324.

Spychała J., Muzeum Archidiecezji Łódzkiej od utworzenia po dziś, „Wędrownik - Biuletyn krajoznawczy. RPK, PTTK w Łodzi”, 3-4 (1994) s. 341.

Szczebak Wł., Muzeum Diecezjalne w Tarnowie, Tarnów 2003.

Wanat B. J., Maryjne Sanktuarium Karmelitów w Czernej. Przewodnik, Kraków 1992.

\section{PROBLEMS AND CHALLENGES OF CHURCH MUSEOLOGY IN POLAND}

\section{Summary}

Religious museums, owned by different denominations, began to emerge in the first half of the nineteenth century. The museums of the Roman Catholic Church are the most numerous ones in this group. Regulations governing the activities of these institutions were included in the Code of Canon Law of 1918 and in the „Papal Directives concerning Church Art" of 1924. This issue was also regulated by a concordat of 1925 between the Republic of Poland and the Holy See. The latest directive is a circular letter of 2001 on Pastoral function of church museums.

Nowadays, a number of religious museums have been created. An important issue is the permanent funding of museums. Another issue is the process of educating future priests in art history, or training church managers in the protection of cultural property. The outlined problems related to church museology indicate various tasks undertaken in this field - at every stage a different one. These tasks are closely connected with the targets set by the organizers and managers of cultural goods.

Keywords: museology, church museums, legal documents, the Code of Canon Law, concordat, monuments 